\title{
The Use Of Online Learning Platform And Inhibiting Factors During The Covid-19 Pandemic Students Department Of Pancasila And Civic Education Class 2020 At PGRI Wiranegara University, Pasuruan City
}

\author{
Ayu Maya Damayanti \\ Department Pancasila and Civic Education PGRI Wiranegara University, Pasuruan City \\ *Coresponding Author \\ Email : bundabimbim99@gmail.com
}

\begin{abstract}
The purpose of this study was to find out the learning platform, as well as the inhibiting factors for the online learning process during the Covid-19 period, students of the Pancasila and Citizenship Education study program class of 2020 at PGRI Wiranegara University, Pasuruan City. This research is a survey research or field study with a qualitative method. Data collection techniques used are interview techniques and questionnaires. Based on the data obtained several learning platforms used during online learning, including: zoom, google meet, google class room, whatApps group, telegram group, LMS (moddle). From the results of data analysis, it was found that the most dominant learning platform used was LMS Mddle. In addition, the respondent's results on the inhibiting factors found several factors, including: 1) limited internet quota; 2) unstable network; 3) difficulty understanding the material delivered from online lecturers; 4) cellphone/laptop facilities.
\end{abstract}

Keyword: E-Learning; Platform; Inhibiting; Covid-19.

\section{INTRODUCTION}

Educational transformation continues to be carried out by our government which is stated in the national goals of educators. Referring to the goals of national education, in learning students become the main characters who play a role in the learning process. To be able to keep up with the times, our students will also be guided through all of that in the form of changes in curriculum regulations that continue to develop (Nursyifa, 2019).

Basically in human life is required to always process. There are many things that always process in human life, one of which is the process of learning. The learning process is a goal-conscious process, namely to improve the cognitive, psychomotor and affective aspects of students. The implementation of this learning process is applied to every process related to the implementation of lectures. Learning is a process of teaching and learning activities that also play a role in determining student learning success. Through learning students can carry out the learning process in accordance with the teaching plan that has been programmed (Anggraeni, 2020).

In order to improve the educational learning process in Indonesia during the Covid-19 pandemic, the Minister of Education and Culture of the Republic of Indonesia through Circular No. 4 of 2020 decided that the teaching and learning process must be carried out from home or what is often called Learning From Home, better know as "Belajar dari Rumah" (BDR). Currently, the study from home policy is applied to approximately 28.6 million students from elementary to high school/vocational school levels in various provinces in Indonesia. As of March 18, 2020, as many as 276 public and private universities in Indonesia have implemented online lectures (Arifa, 2020).

The government also issued Circular No. 15 of 2020 concerning Guidelines for the Implementation of Learning From Home in an Emergency Period Corona Virus Disease 
(Covid-19) which contains: 1) Learning from Home during the emergency spread of Corona Virus Disease (Covid-19) is carried out while still observing the protocol for handling Covid19; and 2) Learning from Home through online and/or offline distance learning is carried out in accordance with the implementation guidelines. Learning from Home as listed in the Attachment to this Circular.

Online learning is learning that is done online, using learning applications and social networks. In this case, the challenges faced, students are required to do online learning. Not only that, lecturers are also required to have competence and master existing technology and information. The constraints in question are the limited ability of students in terms of operating technology as a media to support learning, limited internet quotas and unstable networks that are inhibiting factors for the online learning process. Process system this online learning uses information technology and telecommunications totally (Magdalena et al., 2020).

Some research refer to the results that recovery takes time due to the impact of Covid19, it will take more than a decade to return to normal (Aini, 2021). For this reason, the government and carrying out the transformation and restoration of online learning continue to carry out various learning innovations. Perubahan proses pembelajaran tatap muka menjadi daring memerlukan waktu transisi di lingkungan online. Sistem pembelajaran daring dapat membawa dampak baik dalam pelaksanaannya maupun ketercapaian tujuan pembelajaran (AlIdrus \& Rahmawati, 2021). The distance learning process aims to increase the quality, relevance, equitable access and expansion of education. Learning from home with a distance system organized to improve quality and according to the needs of educators (Fitriya et al., 2021).

Several studies related to the analysis of the inhibiting factors of online learning and the use of learning platforms have been carried out, including: 1) "Implementation and Obstacles to Online Learning During the Covid 19 Pandemic" (Firdaus, 2020) in this study analyzed the implementation and inhibiting factors of online learning, but does not discuss the use of learning platforms used in learning; 2) A similar study was also conducted by (Al-Idrus \& Rahmawati, 2021) with the research title "Analysis of Online Learning Processes During the Covid-19 Pandemic in Chemistry Education Study Program Students, Fkip Unram" in this study discussed the effectiveness of online learning and found three factors barriers to online learning.

From several studies discussing online learning during the COVID-19 pandemic, there has been no research that discusses the use of any platforms used in the online learning process, this needs to be done as a reference for other teachers in utilizing the best appropriate learning platform. condition of the education unit. Another thing that needs to be investigated further is about the inhibiting factors for learning from, where each region or educational unit is determined to have different inhibiting factors. Researchers assume the inhibiting factors will be more varied if examined in other educational units.

From the description above, it can be concluded that a research entitled "The Use Of Online Learning Platform And Inhibiting Factors During The Covid-19 Pandemic Students Department Of Pancasila And Civic Education Class 2020 At Pgri Wiranegara University, Pasuruan City" needs to be carried out so that it can be utilized by the public. on educators.

\section{RESEARCH METHODS}

This research uses qualitative research methods, where the data sources are analyzed using qualitative description techniques. The corpus of data obtained is then interpreted in the form of a description. The first step in this research is to develop a research design and test 
field tools. Next determine the research location, respondents, and informants. In the implementation of field research, observations, documentation and interviews were carried out (Darmalaksana, 2020).

The location of this research was carried out on the campus of PGRI Wiranegara University, Pasuruan City in the Pancasila and Citizenship Education study program class 2020. This study used data collection techniques used by researchers, that is: 1) Interview (Interview), in this interview technique, the researcher carries out a question and answer process that tends to direct the interview to the discovery of the feelings, perceptions, and thoughts of the interviewees regarding the inhibiting factors of the online learning process during the COVID-19pandemic.In this case, the object of the interview or resource person is the student of the Pancasila and Civic Education Program, study program batch 2020 at PGRI Wiranegara University, Pasuruan City. This is intended to identify the reality of the implementation of the online learning process. The results of this research are expected to be able to provide information and evaluate the implementation of the online learning process. Pancasila and Civic Education Program in class of 2020; 2) Literature Research (Library Research), in the literature study technique, researchers conduct research by studying and reading literature that has to do with the problems that are the object of research. Literatures that can support research include books, scientific articles, internet websites that provide various information relevant to the problems in this research.

\section{RESULTS AND DISCUSSION}

The results of the research "Analysis of Online Learning Inhibiting Factors During The COVID-19Pandemic Students Of Pancasila Education And Civic Study Program For 2020 At The University Of Pgri Wiranegara Pasuruan City" the researcher made observations in the form of distributing questionnaires which contained several questions regarding the learning platform used by Pancasila and Citizenship Education students in the class of 2020, before analyzing the factors that hinder online learning during the current COVID-19pandemic. Students can choose more than one platform used by them in the online learning process. The following data findings from research results concerning the use of the online learning platform can be seen in the following table:

\begin{tabular}{ccc}
\hline No. & Learning platform & $\begin{array}{c}\text { Number of } \\
\text { respondents }\end{array}$ \\
\hline 1 & Zoom & 10 \\
\hline 2 & Google meet & 15 \\
\hline 3 & Google classroom & 2 \\
\hline 4 & WhatApp group & 20 \\
\hline 5 & Telegram group & 15 \\
\hline 6 & LMS (Modle) & 32 \\
\hline
\end{tabular}

Table 1. Platform pembelajaran daring

From the data in the table above, it can be seen that several learning platforms have been used by lecturers and students in the learning process, including: 1) Zoom, zoom is a learning platform that is used for online virtual face-to-face. From the results of respondents, there are 10 lecturers and students who take advantage of the application in the learning process; 2) Google meet, the platform is also a learning medium that provides interactive learning in the form of virtual face-to-face. The results of respondents on the use of the 
application were 15 lecturers and students who used the application; 3) google class room, the platform is also a learning medium that is used as an online learning platform, but the platform is in the form of asynchronous learning (without face to face), and as many as 2 respondents; 4) WhatApp group, also an application that is often used by lecturers and students as an online learning medium, even though the learning is done in the form of interactive chat; 5) Telegram Group, the application has also been developed to be used as a learning platform that not only functions as asynchronous learning, but also produces interactive features that provide synchronous learning (virtual gaze); 6) LMS Moddle, a learning platform that dominates the use of media/learning facilities, because in LMS Moddle, synchronous and asynchronous learning features are presented in detail and complete, up to the evaluation process. The number of respondents who stated that the use of the platform was 32 respondents.

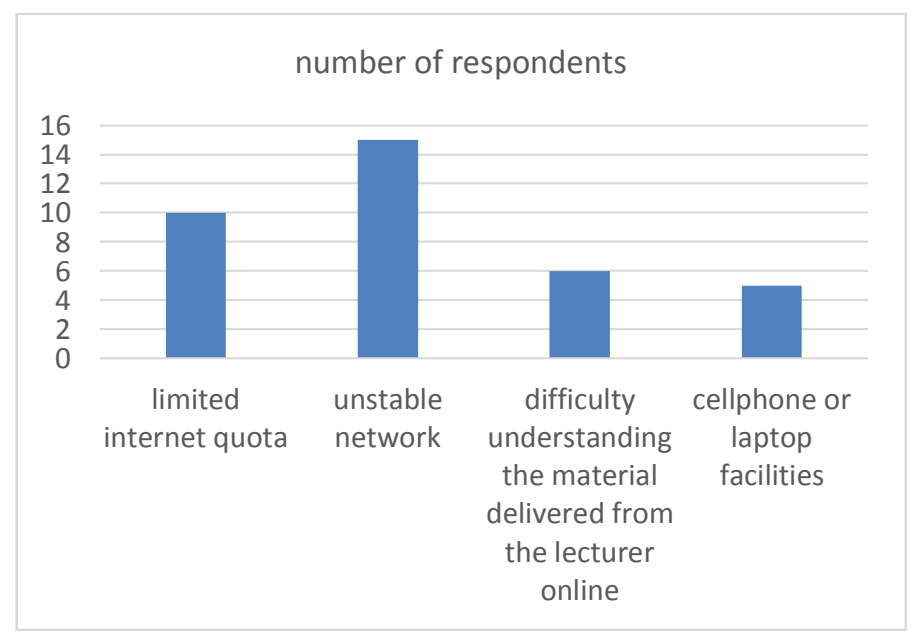

Graph 1. Factors Inhibiting Online Learning

During the COVID-19 pandemic, learning carried out in Indonesia was still carried out with various implementations of learning patterns initiated by the government. One of the ways to overcome the problems of face-to-face learning and learning efficiency, then appear learning rules that are carried out online. This application is applied to each element and level of the educational unit. Starting from Play Ground, SD, SMP, SMA / SMK, and University. There are several innovations made by several teachers and lecturers in implementing the online learning. Several learning platforms are used by several educators. This really helps the efficiency of learning to keep it going even during a pandemic with limited face-to-face. However, in addition to the use of online learning platforms that have been implemented by some educators, it is very helpful for students in the learning process, there are also some obstacles experienced by students during the online learning process. From the results of the study, it was found that several factors inhibited the online learning process during the covid-19 pandemic at the PGRI Wiranegara university, Department in Pancasila and civic education, including: 1) limited internet quota, as many as 10 respondents stated difficulties in getting internet quota. One of the underlying factors is the family's economic limitations; 2) Unstable internet network, another factor that hinders the learning process is the internet network, this is most often experienced by students who come from rural or mountainous areas, so that their internet network is less stable and even does not get internet access at all. This can be seen in the results of respondents who answered as many as 15 respondents; 3) the third factor that becomes an 
obstacle to online learning, namely as many as 6 respondents who answered difficulties in understanding lecture material delivered online; 4) smart phone or laptop facilities are also one of the inhibiting factors for online learning, this can be seen in a number of 5 respondents who answered that HP and laptop facilities were also one of the obstacles to the implementation of online learning.

\section{CONCLUSION}

Based on the research, it can be concluded that online learning carried out by students of the Pancasila and Citizenship Education study program at PGRI Wiranegara University, which consists of various activities, namely core introduction and In closing, there are factors that hinder the online learning process. The main inhibiting factor is the internet network, if the internet network used is unstable or the internet quota data package is inadequate to take online lectures, the online lecture process will be hampered. This is also related to economic factors that cannot be denied, because the online lecture process consumes more internet quota. The readiness of lecturers and students in adapting to the lecture process is also an inhibiting factor, because considering that the previous lecture process was carried out offline or offline in this case, it was face to face. Therefore, efforts are needed in terms of improving the online lecture process while remaining oriented to the achievement of lectures that will be achieved by students in the future

\section{REFERENCES}

Aini, K. (2021). Analisis Proses Pembelajaran Daring pada Masa Pandemi Covid 19. Jurnal Studi Guru Dan Pembelajaran, 4(1), 218-228.

Al-Idrus, S. W., \& Rahmawati, R. (2021). Analisis Proses Pembelajaran Daring Selama Pandemi Covid-19 pada Mahasiswa Program Studi Pendidikan Kimia FKIP UNRAM. Pensa, 3(1), 139-148.

Anggraeni, A. (2020). Menegaskan Manusia Sebagai Objek dan Subjek Ilmu Pendidikan. Jurnal PPKn \& Hukum, 15(1), 64.

Arifa, F. N. (2020). Tantangan pelaksanaan kebijakan belajar dari rumah dalam masa darurat covid-19. Info Singkat: Kajian Singkat Terhadap Isu Aktual Dan Strategis, 7(1), 13-18.

Darmalaksana, W. (2020). Metode Penelitian Kualitatif Studi Pustaka dan Studi Lapangan. PrePrint Digital Library UIN Sunan Gunung Djati Bandung, 1-6.

Fitriya, D., Magdalena, I., \& Fauziah Fadhillahwati, N. (2021). Konsep Pembelajaran Daring di Era Pandemi Covid-19. Cerdika: Jurnal Ilmiah Indonesia, 1(3), 182-188. https://doi.org/10.36418/cerdika.v1i3.30

Magdalena, I., Salsabila, A., Krianasari, D., A., \& Apsarini, S., F. (2020). Implementasi Model Pembelajaran Daring Pada Masa Pandemi Covid-19 Di Kelas IIII SDN Sindangsari III. Jurnal Pendidikan Dan Dakwah, 3(1), 119-128. 
Email : editorijhess@gmail.com

Nursyifa, A. (2019). Transformasi Pendidikan Ilmu Pengetahuan Sosial dalam Menghadapi Era Revolusi Industri 4.0. Jurnal Pendidikan Kewarganegaraan, 6(1), 51. https://doi.org/10.32493/jpkn.v6i1.y2019.p51-64 